新しい $\beta$ 遮断剂 Metoprolol 投与の効果 に関する臨床的研究

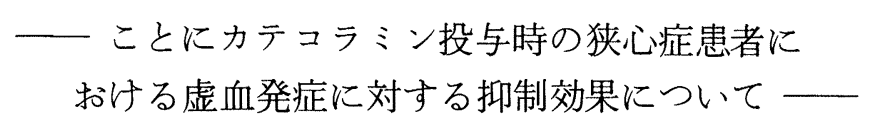

$$
\begin{array}{lll}
\text { 宮 原 光 } *^{* 1} & \text { 東海林哲 郎*1 } \\
\text { 浜 上 裕 }{ }^{* 2} & \text { 浜辺 晃*3 }
\end{array}
$$

（受付：1978 年 3 月 13 日）

Inhibitory Effect of Metoprolol, a New Cardioselective $\beta$-Blockade, on Catecholamine-Induced Cardiac Ischemia

A Clinical Study
Mitsuo MIYAHARA*1 Tetsuro SHOJI*1 ${ }^{* 1}$ Yuichi HAMAGAMI*2 and Akira HAMABE*3

${ }^{* 1}$ Second Department of Internal Medicine, Sapporo Medical College

*2 Section of Internal Medicine, Furano Kyokai Hospital

*3 Section of Internal Medicine, Sapporo Hokushin Hospital

I . An inhibitory effect of intravenously administered $10 \mathrm{mg}$ metoprolol on isoproterenol-induced cardiac acceleration was compared with that of $10 \mathrm{mg}$ propranolol and $40 \mathrm{mg}$ practolol based on hemodynamics and mechanocardiogram in ten healthy controls.

1) Intravenously administered metoprolol produced a significant decrease in heart rate (HR), systolic blood pressure (sBP), cardiac effort index (CEI) and an elongation of corrected preejection period (PEPc) and isometric contraction period (ICP) and an increase of PEPc/ET (ET : ejection time). While propranolol produced a significant rise in diastolic blood pressure $(\mathrm{dBP})$ and no change in $\mathrm{sBP}$, the other effects produced by metoprolol were almost same as those obtained by propranolol. Practolol did not produce any significant effect.

\footnotetext{
${ }^{* 1}$ 札幌医大第二内科

*2 富良野協会病院内科

*3 札幌北辰病院内科
} 
2) Although isoproterenol induced cardiac acceleration (tachycardia, increase of $\mathrm{sBP}$, decrease of $\mathrm{dBP}$, shortening of PEPc and ICP, and decrease of PEPc/ET) was inhibited significantly by propranolol, both metoprolol and practolol did not inhibit it.

II. An inhibitory effect of orally administered metoprolol on catecholamine-induced cardiac ischemia was compared with that of practolol based on clinical symptoms, hemodynamics and electrocardiogram (ECG) in eleven patients with angina pectoris.

1) Orally administered $40 \mathrm{mg}$ of metoprolol produced a significant decrease in heart rate, $\mathrm{CEI}$ and pressure rate index (PRI). The effect was more marked than that obtained with $100 \mathrm{mg}$ of practolol.

2) Both metoprolol and practolol

a) maintained low levels of heart rate, CEI and PRI, inhibited ischemic alterations of ECG, and reduced anginal episodes following adrenaline administration;

b) did not inhibit the elevation of blood pressure, but maintained heart rate, CEI and PRI at low levels and inhibited ischemic alterations of ECG produced by noradrenaline;

c) inhibited tachycardia, increase of CEI and PRI, ischemic alterations of ECG and anginal episodes produced by isoproterenol.

Metoprolol $40 \mathrm{mg}$ was clearly effective in inhibiting catecholamine-induced angina and equivalent to, or more effective than, practolol $100 \mathrm{mg}$.

\section{序 言}

Di-dl-[1-isopropylamino-3- $\{\mathrm{p}-(2-$ methoxyethyl)-phenoxy $\}$-2-propanol\} - $(+)$-tartrate: metoprolol tartrate (以下 metoprolol) は新しく 開発された $\beta$ 遮断剂の一つで, 血管拉よび気管支 平滑筋の抑制作用は弱く, いわゆる心臓選択性で, かつ内因性交感神経刺激作用および膜安定作用を 持たないといわれる12).

今回著者らは本剂の臨床効果とその特性を明ら かにする目的で次の実験を行った。すなわち，ま ず健康成人で, isoproterenol (IP) 持続投与に対す る metoprolol i.v. の効果を, 血圧, 心電図, 心機 図の面から検討し，これを propranolol ならびに 同じく心臟選択性で膜安定作用を持たないが，内 因性交感神経刺激作用を有する $\beta$ 遮断剂といわ
れる practolol の効果と対比した. 次に狭心症患 者の catecholamine (CA) 負荷による虚血発症時 の臨床症状，血行動態ならびに心電図変化に対す る metoprolol p. o. の効果を検討し, 同様条件下 の practolol p. o. の効果と比較した.

なお，ここで使用した量の CA 投与で，既に報 告した如く ${ }^{3 / 4)}$, 大多数の狭心症患者に心電図上, 虚血性変化が出現するので, これは薬物負荷試験 として臨床診断にも応用しうるものである。また IP の投与量は心拍数, Max $\mathrm{dP} / \mathrm{dt}$ よりみた心筋 収縮性の変化から, 上述の CA量とほぼ同力価と 推測される量 ${ }^{5}$ である.

これらの試験は昭和 49 年 10 月より昭和 52 年 3 月までに行った。 


\section{対象ならびに方法}

I . Metoprolol i. v. の効果と他 $\beta$ 遮断剤のそれ との比較

健常成人男子 10 例（15２8 歳：平均 21 歳）を 対象とし，いずれも早朝， $30 \mathrm{~min}$ 臥床安静後，第 1 日は metoprolol $10 \mathrm{mg}$, 第 2 日は propranolol $10 \mathrm{mg}$ ，第 3 日は practolol $40 \mathrm{mg}$ をi. v. 投与し た。投与前拈よび投与後 $20 \mathrm{~min}$ まで $5 \mathrm{~min}$ 毎に 聴診法による血圧 (BP) と Schwartzer P 622 を 用いて心電図，心音図，頸動脈波，心尖拍動図を 同時記録した。 心拍数 (HR), isometric contraction period (ICP), preejection period (PEP), corrected preejection period $(\mathrm{PEPC})$, ejection time (ET)を計測しまた PEP/ET 比および心負担係 数 ( $\mathrm{HR} \times$ 平均血圧) $(\mathrm{CEI})$ を算出した。な打投与 後の諸值は各 $\beta$ 遮断剂 i.v. 後 $20 \min$ の值をもっ てした。一方上述対象のらちの 5 例には，第 1 日 目の前日, 臥床安静下に IP $0.02 \mu \mathrm{g} / \mathrm{kg} / \mathrm{min}$, 第 1,2,3 日目はそれぞれ metoprolol, propranolol, practolol 投与 $20 \mathrm{~min}$ 後より同量の IP を投 与, いずれも IP 点滴 $20 \mathrm{~min}$ 後に上述諸量の測定 を行った。
II. 労作性狭心症患者に打ける CA 負荷試験に 対する metoprolol p.o. ならびに practolol のそ れとの比較

札幌医科大学第二内科括よび富良野協会病院内 科入院中の労作性狭心症患者で, 未治療もしくは 抗狭心症薬投与中止後 1 週間以上を経過せる男子 8 , 女子 3 , 計 11 例（41 74 歳: 平均 57.7 歳） を対象とし以下の検索を行った。

1) Metoprolol, practolol 単独投与の効果

各症例につき, 次項に述べる各 CA 単独投与の 効果をみた翌日ならびに翌々日に，早朝臥床安静 $30 \mathrm{~min}$ 後, metoprolol 10 または $40 \mathrm{mg}$, practolol $100 \mathrm{mg}$ を p. o. 投与し $90 \sim 120 \mathrm{~min}$ 後に $\beta$ 遮断剂 自体の効果を検討した。

2) CA 負荷に対する metoprolol ならびに practolol の効果

第 1 日目に臥床安静 $30 \mathrm{~min}$ 後, adrenaline (Ad) $0.1 \mu \mathrm{g} / \mathrm{kg} / \mathrm{min}$ 点滴 i. v., 第 2,3 日目 にはそれぞれ metoprolol 10 または $40 \mathrm{mg}$, practolol $100 \mathrm{mg}$ の p. o. 投与 $90 \sim 120 \mathrm{~min}$ 後に同じ < Ad を点滴 i.v. し,第 1 日の $\beta$ 遮断剂非投与時 の Ad 効果と対比した。 またこのうち 5 例につい ては,引き続き同様の日程で noradrenaline (NA)

Table 1 各狭心症患者に施行されたカテコラミン負荷試験と, それに対する $\beta$ 遮断剤前投与の内訳

\begin{tabular}{|c|c|c|c|c|c|c|c|c|c|c|}
\hline \multirow{2}{*}{$\underbrace{\text { CA 前投与 }}_{\text {症例 }}$} & \multicolumn{4}{|c|}{$\mathrm{Ad}$} & \multicolumn{3}{|c|}{ NA } & \multicolumn{3}{|c|}{ IP } \\
\hline & - & Mt 10 & Mt 40 & Pract & - & Mt 40 & Pract & - & Mt 40 & Pract \\
\hline $\begin{array}{cc}\text { 1. 女 } & 58 \text { 歳 } \\
2 \text {. 男 } & 45 \text { 歳 } \\
\text { 3. 男 } & 41 \text { 歳 } \\
\text { 4. 男 } & 46 \text { 歳 } \\
\text { 5. 女 } & 59 \text { 歳 } \\
\text { 6. 女 } & 59 \text { 歳 } \\
\text { 7. 男 } & 72 \text { 歳 } \\
\text { 8. 男 } & 49 \text { 歳 } \\
\text { 9. 男 } & 72 \text { 歳 } \\
\text { 10. 男 } & 60 \text { 歳 } \\
\text { 11. 男 } & 74 \text { 歳 }\end{array}$ & $\begin{array}{l}0 \\
0 \\
0 \\
0 \\
0 \\
0 \\
0 \\
0 \\
0 \\
0 \\
0\end{array}$ & $\begin{array}{l}0 \\
0 \\
0\end{array}$ & $\begin{array}{l}0 \\
0 \\
0 \\
0 \\
0 \\
0 \\
0 \\
0 \\
0\end{array}$ & $\begin{array}{l}0 \\
0 \\
0 \\
0 \\
0 \\
0 \\
0 \\
0 \\
0 \\
0 \\
0\end{array}$ & $\begin{array}{l}0 \\
\bigcirc \\
0\end{array}$ & $\begin{array}{l}0 \\
0 \\
0\end{array}$ & $\begin{array}{l}0 \\
0 \\
0\end{array}$ & $\begin{array}{l}0 \\
0 \\
0\end{array}$ & $\begin{array}{l}0 \\
0 \\
0\end{array}$ & $\begin{array}{l}0 \\
\bigcirc \\
0\end{array}$ \\
\hline 合計 例 数 & 11 & 3 & 9 & 11 & 5 & 5 & 5 & 5 & 5 & 5 \\
\hline
\end{tabular}

Mt 10 : metoprolol 10 mg Mt 40 : metoprolol $40 \mathrm{mg}$ Pract : practolol $100 \mathrm{mg}$ 
0.2 および IP $0.02 \mu \mathrm{g} / \mathrm{kg} / \mathrm{min}$ 投与に対する metoprolol, practolol の抑制効果を反復して検討 した. 施行した $\mathrm{CA}$ 負荷と $\beta$ 遮断剤投与量の組み 合わせを症例毎に Table 1 に示す. 以上の実験 で，第 1 日は Ad, NA, IP 投与前後, 第 2，3 日 は $\beta$ 遮断剂投与前後拉よび引き続き Ad, NA, IP 投与後に $\mathrm{BP}$, 心電図を記録, CEI, pressure rate index (PRI : 心拍数 $\times$ 収縮期血圧) を算出した. な扛 CA 負荷前後の諸量は途中狭心痛を訴えた
ものはその時点の，しからざるものは $15 \mathrm{~min}$ 後 の変化をもってした．心電図変化は, 12 誘導中に みられた最も顕著な ST 変化を用いて比較した。

統計学的処理は Student T test (対応ある平均 值の差の検定）により行った.

\section{成 績}

I. Metoprolol i. v. の効果

各 $\beta$ 遮断剂投与前後の $\mathrm{HR}, \mathrm{BP}, \mathrm{CEI}, \mathrm{PEPc}$,
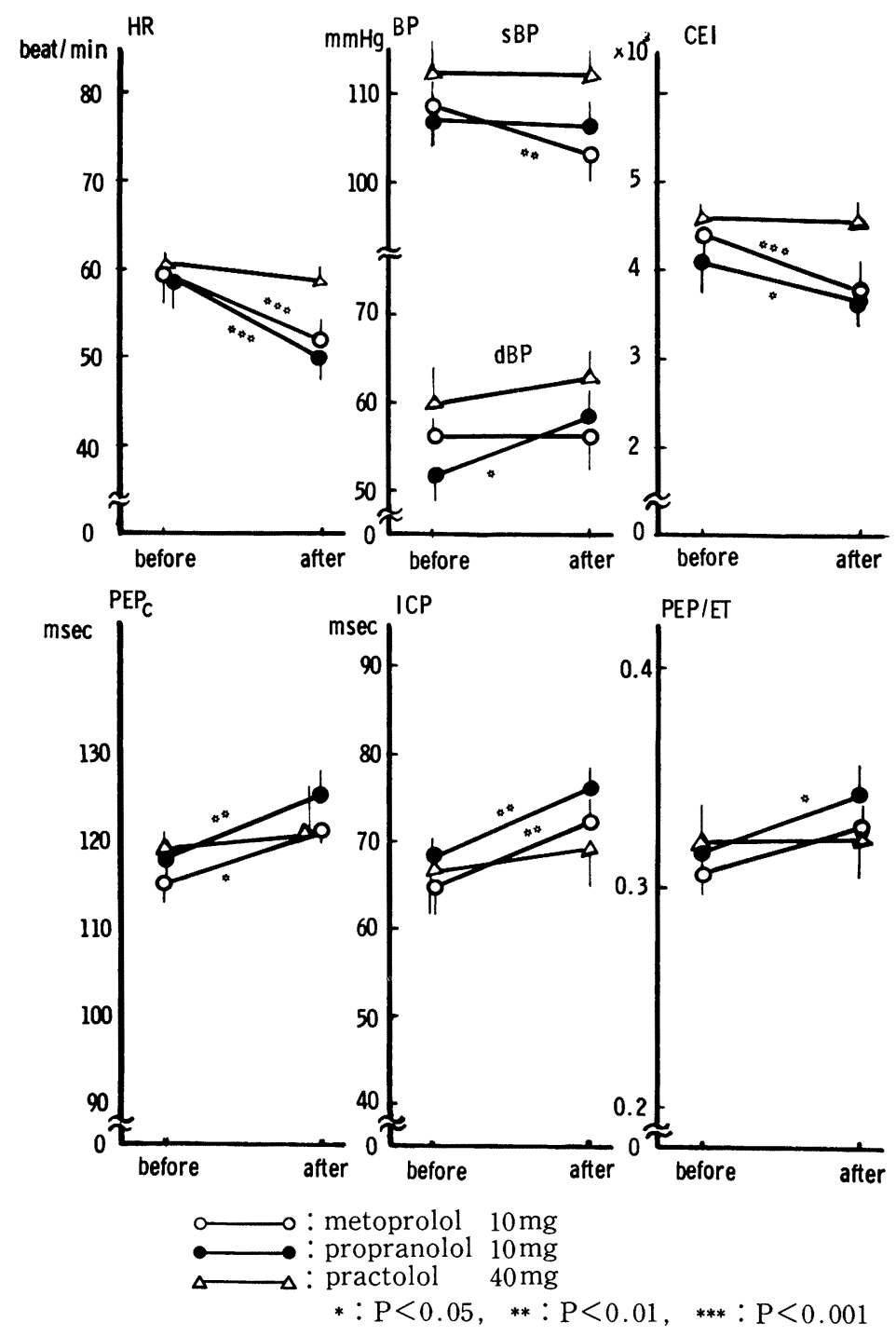

Fig. $1 \beta$ 遮断剤 i.v. 投与前後の変化. 

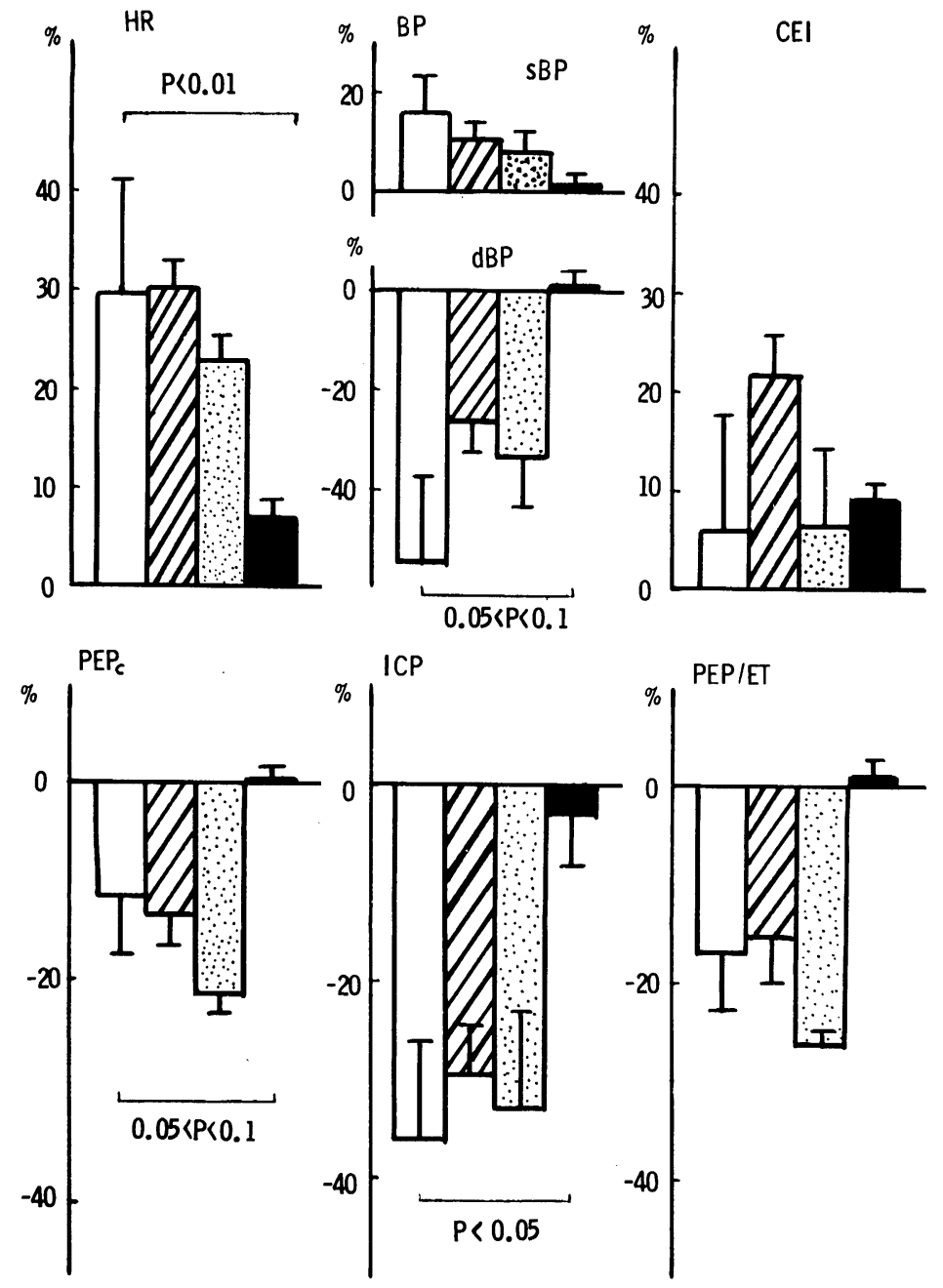

$\square$ ：対照, WIIA：metoprolol 10mg

: practolol $40 \mathrm{mg}$

propranolol $10 \mathrm{mg}$

Fig. 2 IP 負荷に対する各 $\beta$ 遮断剤の効果 ( 5 例).

ICP, PEP/ET を Fig. 1 に示す.

まず HR(1 min 間)は metoprolol により $-8 \pm$ 1 (Mean \pm SE), propranolol でー $9 \pm 1$ といずれ も有意に低下するが, practolol による変化（一 $2 \pm 1$ ) は有意ではない, 収縮期血圧 (sBP) は metoprolol により軽度ではあるが有意 $(-5 \pm 1$ mmHg) に低下し, propranolol, practolol では不 変である。 また拡張期血圧 $(\mathrm{dBP})$ は metoprolol, practolol で明らかな変化は示さず, propranolol
で有意に上昇する. CEI は metoprolol, propranolol によりいずれも有意に低下し，practolol で は不変である.

PEPc, ICP は metoprolol, propranolol により いずれも有意に延長するが, practolol では有意な 変化を示さない. PEP/ET は propranolol で有意 に上昇し, metoprolol も同様傾向を示すが有意で なく, practolol では不変である.

次に $\beta$ 遮断剂非投与時と投与後の IP 負荷によ 


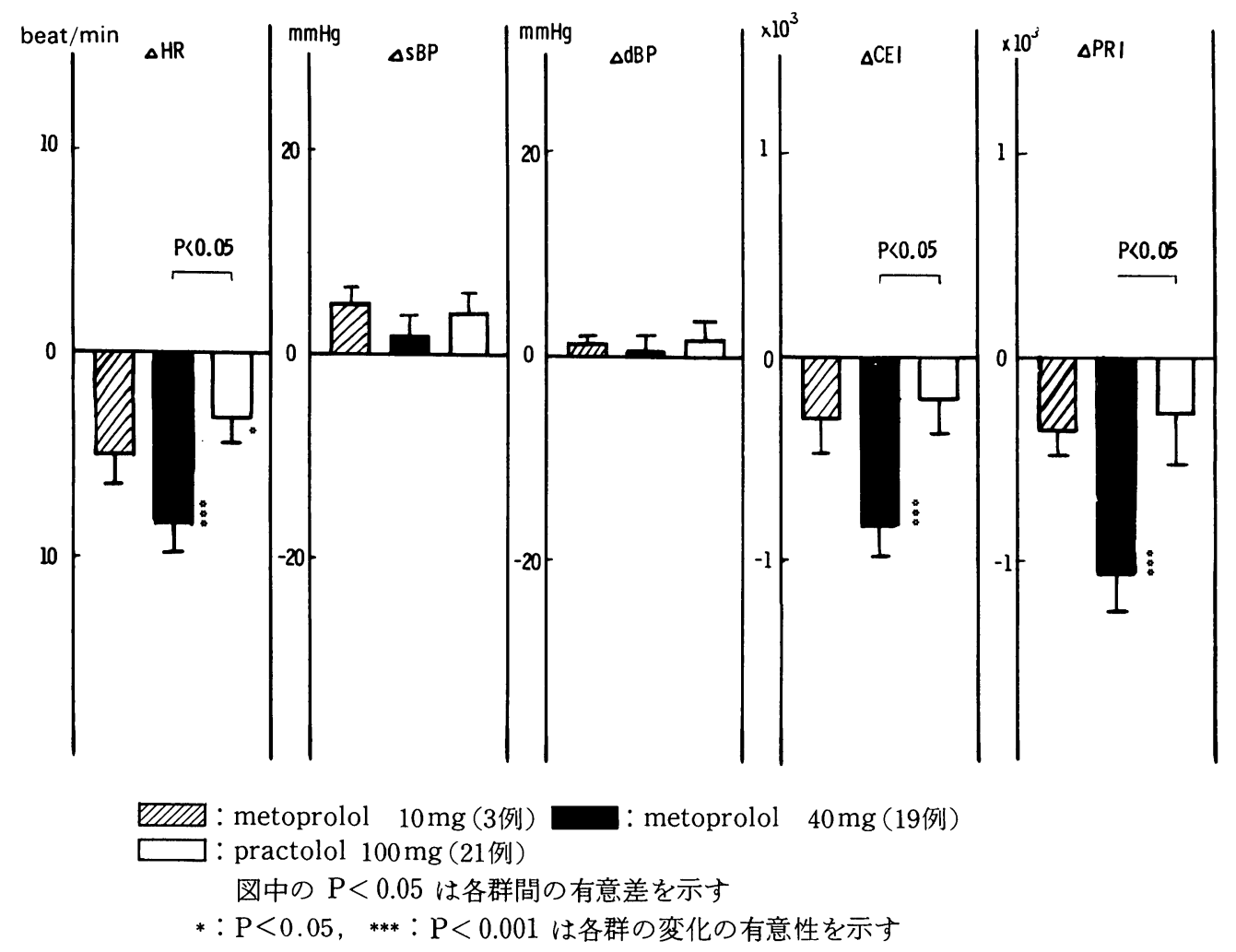

Fig. $3 \beta$ 遮断斉 p.o. 投与による影響.

る諸量の変化を, IP 投与前に対する\%变化とし， 一括して Fig. 2 に示す。まずHR は，IPによる 著しい増加を, propranolol は有意に抑制するが, metoprolol, practolol では抑制効果は明らかでな い. $\mathrm{BP}$ は, IP による $\mathrm{sBP}$ 上昇, $\mathrm{dBP}$ 下降が 3 種の $\beta$ 遮断剂によりいずれも軽度となるが有意 の変化でない.CEI は IP による $5.4 \pm 12.4 \%$ の上 昇が, practolol, propranolol で著変なく, metoprolol ではむしろ増強されるがこれまた有意では ない.

$\mathrm{PEPc}, \mathrm{ICP}, \mathrm{PEP} / \mathrm{ET}$ はいずれも IP により著 しく低下し， propranolol はこれらを著明に抑制 し，殊に ICP に拈ける効果は有意である。これに 対し, metoprolol, practolol では抑制効果はみら れず, propranolol とは明らかな差異が認められ る.つまり IP による HR 増加, $\mathrm{dBP}$ の低下，心 機能促進効果を propranolol は明らかに抑制した が, metoprolol では practolol 同様かかる抑制効
果は明らかではなかった。

II. 労作性狭心症患者に打ける metoprolol, practolol p. o. の効果

1) Metoprolol, practolol 単独の効果

Metoprolol $10 \mathrm{mg}$ ( 3 例 3 回), 同 $40 \mathrm{mg}$ ( 9 例 19 回), および practolol $100 \mathrm{mg}$ (11 例 21 回) p. o. 前後の HR, sBP, dBP, CEI, PRI の変化値を Fig. 3 に示す.

HR の減少は metoprolol $40 \mathrm{mg}$ および practolol で有意で, かつ前者の効果は後者に比し有意 に強い. BP については, metoprolol, practolol に より, $\mathrm{sBP}, \mathrm{dBP}$ 共に平均值ではやや高值となる が, いずれも有意の変化ではない.一方 CEI, PRI は metoprolol $40 \mathrm{mg}$ で有意に低下し，この抑制効 果は practolol の効果に比すれば明らかに強い. なお metoprolol $10 \mathrm{mg}$ による変化は practolol のそれに近似する。 
（症例 島○行○ 41 歳令）

$\mathrm{ST}$ 低下 $(\mathrm{mm})$ 狭心痛 CEI
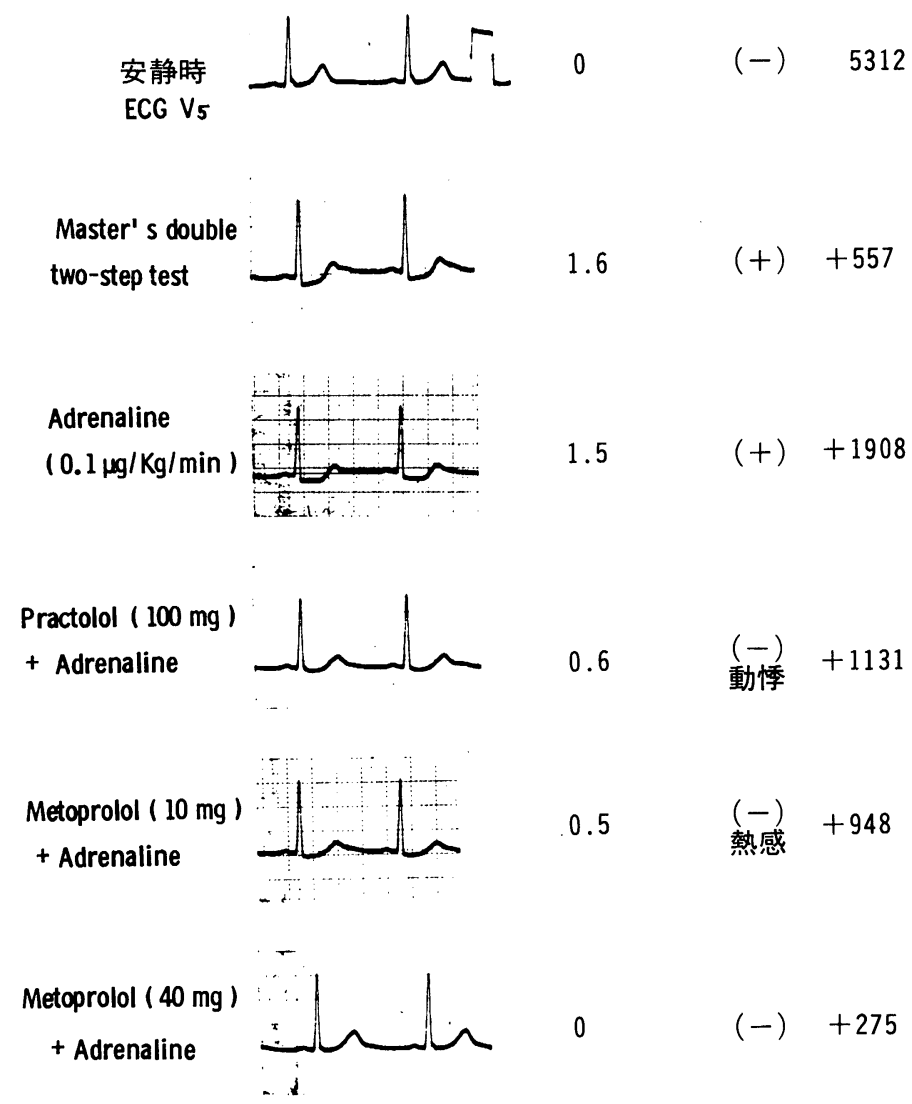

Fig. $4 \mathrm{Ad}$ 負荷により生じた虚血性変化と, それに対する各 $\beta$ 遮断剂の効果が典型的で あった狭心症患者の 1 例.

2) Ad 負荷に対する metoprolol の効果

まず Ad 負荷により生ずる虚血性変化が metoprolol $10 \mathrm{mg}$ ならびに $40 \mathrm{mg}$ により抑制された 典型例を, practolol $100 \mathrm{mg}$ の効果と対比し Fig. 4 に示す.

本例ではAd 負荷により Master 2 階段 2 重負 荷に相当する ST 低下と狭心痛の出現をみた。し かし, metoprolol $10 \mathrm{mg}$ 投与により Ad 投与時の $\mathrm{ST}$ 低下, CEI の上昇は practolol $100 \mathrm{mg}$ と同程 度に軽減し，狭心痛は出現しなかった。ささらに metoprolol $40 \mathrm{mg}$ の前投与では, もはや狭心痛は 勿論, ST 変化もみられず，また CEI の上昇もほ ぼ完全に抑制された。
次に Fig. 5 に 遮断剂非投与 (対照), metoprolol $40 \mathrm{mg}$ 抢よび practolol $100 \mathrm{mg}$ 投与後に Ad 負荷を同一例で行いえた 9 例について，負荷 前後の $\mathrm{HR}, \mathrm{sBP}, \mathrm{dBP}, \mathrm{CEI}, \mathrm{PRI}$, 心電図 ST を Mean \pm SE で示す.

まず HR においては Ad 負荷による増加値は 三者間で差をみず，負荷後值は非投与対照群, practolol 群, metoprolol 群の順に低值となる. 次に Ad 負荷による $\mathrm{sBP}$ の上昇は対照执よび practolol 投与後では有意であるが, metoprolol 投与後ではやや抑制され有意の上昇ではない。 dBP はいずれに抢いても有意な変化を示さない。 そして CEI, PRI は Ad 単独, metoprolol, prac- 


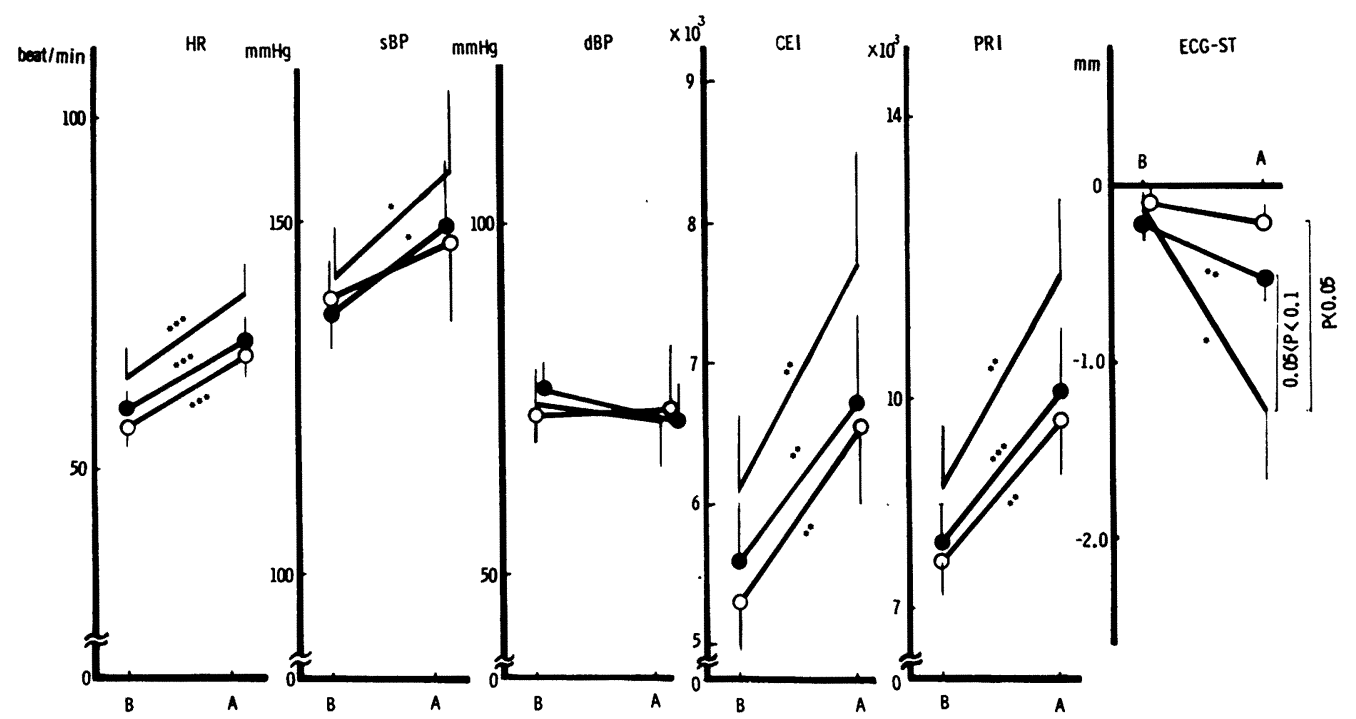

Fig. 5 狭心症患者に拈ける Ad 負荷に対する metoprolol, practolol の効果 (9 例).

B : before, A : after

$\longrightarrow$ : 対照, $\rightleftharpoons$ : metoprolol $40 \mathrm{mg}$

$*: \mathrm{P}<0.05,{ }^{* *}: \mathrm{P}<0.01,{ }^{* * *}: \mathrm{P}<0.001$ はいずれも $\mathrm{B}-\mathrm{A}$ 間の有意差

$\mathrm{p}:$ 各群間の有意差

tolol 投与後ではいずれも有意の増加を示す.しか しながら注目すべきは，Ad 投与前值は metoprolol 群でもっとも低く, 次いで practolol といずれ も対照より低值を示し，そのために Ad 投与後値 も同様に metoprolol でもっとも低值である.さ らに心電図 ST は対照の Ad による有意な低下 が, metoprolol, practolol により抑制され，特に 前者でその効果は著しく，有意の ST 低下はみら れない。な技Ad 負荷時の狭心痛出現は 9 例中, $\beta$ 遮断剂非投与時には 7 例, metoprolol 投与後は 2 例， practolol 投与後は 3 例であった.

3) NA 負荷に対する metoprolol の効果

$\beta$ 遮断剂非投与(対照), metoprolol $40 \mathrm{mg}$ およ び practolol $100 \mathrm{mg}$ 投与後のいずれにも NA 負 荷を行いえた 5 例について，NA 投与前後の HR， $\mathrm{sBP}, \mathrm{dBP}, \mathrm{CEI}, \mathrm{PRI}$, 心電図 ST を Mean $\pm \mathrm{SE}$ で Fig. 6 に示す.

HR は NA 負荷によりいずれの群も明らかな 変化を示さないが，負荷前值は metoprolol で
もっとも低く,そのために NA 負荷後値も同様に 低い. sBP と dBP は NA によりいずれの群でも 著明に上昇し，三者間に差異をみない。その結果 NA による CEI, PRI の上昇程度には 3 者間で明 らかな差を見出しえないが, metoprolol 投与後は 負荷前値がすでに低く，後値も対照より低い值を 維持し, practolol は両者の中間の值をとる.なお 心電図 ST は NA により対照では 5 例中 3 例が $0.5 \mathrm{~mm}$ 以上低下し，亏ち 1 例は胸部圧迫感を訴え たが， metoprolol 投与後は 1 例のみが $0.3 \mathrm{~mm}$ の，また practolol も 1 例に $0.2 \mathrm{~mm}$ の低下をみる 以外は不変であり, 両者とも狭心痛の出現は認め られなかった。

4 ）IP 負荷に対する metoprolol の効果

NA 同様の条件で, IP 負荷に対する metoprolol, practolol の効果を検討しえた 5 例の Mean士 SE を Fig. 7 に示す.

まず HR は，IP による著しい上昇が，metoprolol, practolol いずれによっても明らかに抑制 


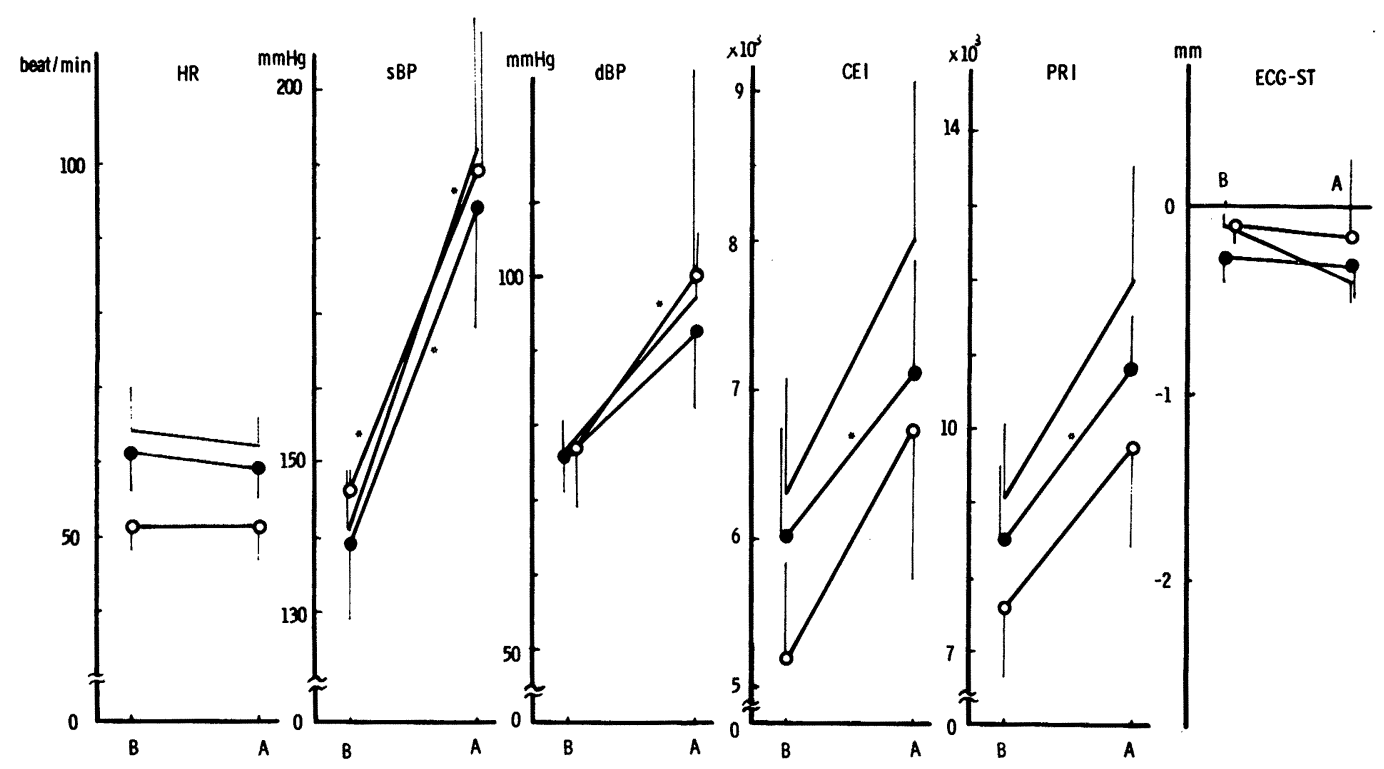

Fig. 6 狭心症患者に扣ける NA 負荷に対する metoprolol, practolol の効果 ( 5 例). 略号は Fig. 5 に同じ.

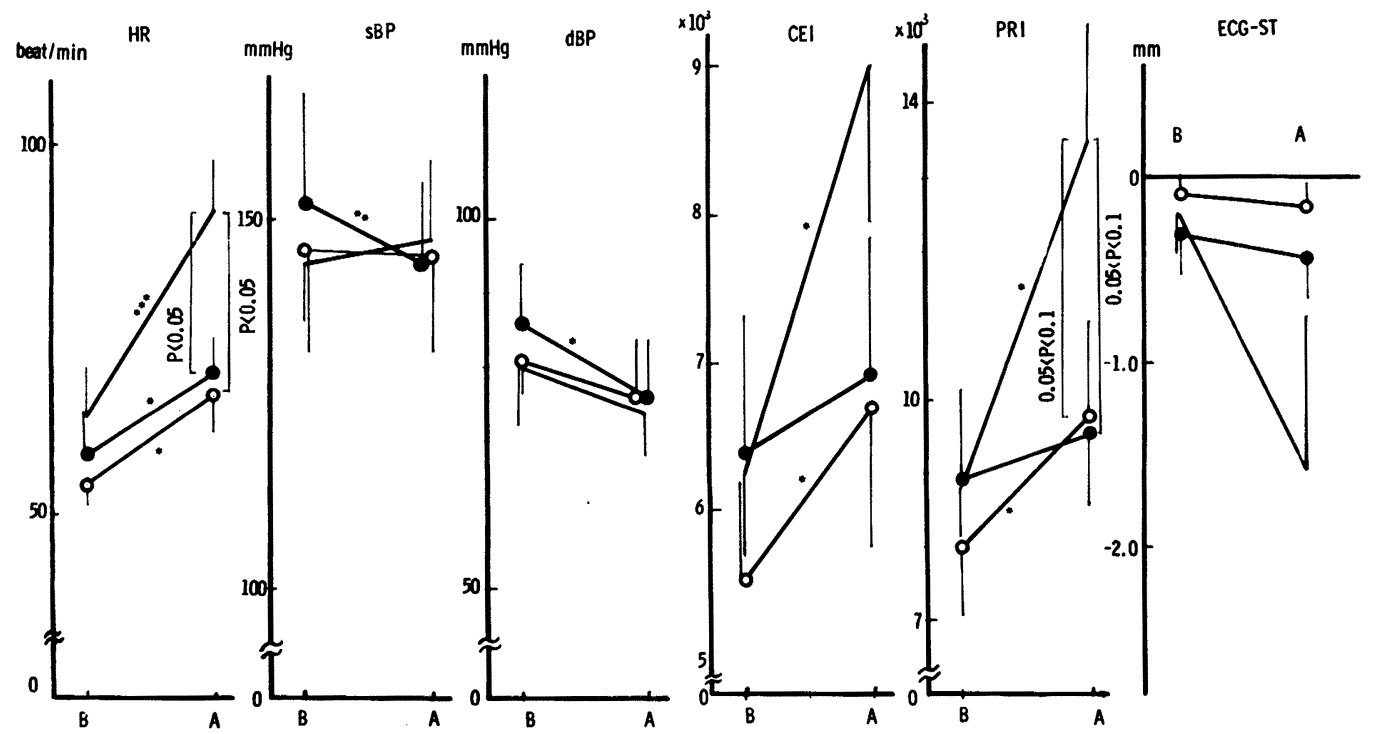

Fig. 7 狭心症患者に打ける IP 負荷に対する metoprolol, practolol の効果（5 例). 略号は Fig. 5 に同じ.

され, IP 負荷後の值は対照群のそれに比し有意に た值となった. そして CEI と PRI は対照では IP 低い. sBP はIP により対照, metoprolol 後いず により著明に上昇するが，この上昇は practolol, れも不変で, practolol 後のみ低下し, $\mathrm{dBP}$ は三者 metoprolol, 特に前者で抑制され, かつ IP 負荷後 ともに極く軽度に低下し, 負荷後值はほぼ近似しの值は両者とも対照より低く, 殊に PRI でその傾 
向が強い. 他方心電図 ST は, IP により対照では 全例 $0.5 \mathrm{~mm}$ 以上低下し，5例中 3 例に狭心痛が 出現したが, metoprolol, practolol 投与後は共に 5 例中同一の 1 例のみに, 前者で $0.3 \mathrm{~mm}$, 後者で $0.5 \mathrm{~mm}$ の低下をみた以外に著変なく,狭心痛の出 現も認められなかった。

\section{考 案}

I . 健常人に拈ける metoprolol i. v. の効果

まず本剂の薬理効果をみるべく健常人に metoprolol $10 \mathrm{mg}$ をi. v. 投与し, 効果が安定した 20 min 後の值をとり, propranolol $10 \mathrm{mg}$ および practolol $40 \mathrm{mg}$ の効果と対比した. その結果, metoprolol, propranolol により HR は減少し, CEI は低下し, 心機図上 ICP, PEPc はいずれも延 長し，PEP/ET は上昇した. しかし practolol で はこれらの効果は明らかでない。つまり本実験に 用いた投与量では metoprolol は propranolol に 近似する徐脈効果と，心機図よりみた心機能抑制 効果を示し, practolol はいずれの効果も前二者 より弱い. 本実験では, 動物実験で IP 反応性に対 する各種 $\beta$ 遮断剂の効果を比較した Åblad らの 成績 ${ }^{1}$ をもとに, practolol の投与量を $40 \mathrm{mg}$ とし 検討したが, この量では心拍数，心機能に対する 抑制効果は他剂より明らかに弱い。他方 HR と平 均血圧より算出される CEI については, metoprolol は HR, sBP 両者の低下により三者間で最 も著しく低下し, propranolol は HR は低下する が dBP は上昇し, CEI の低下は metoprolol より はやや弱く, practolol は HR, BP 共に変わらず CEI も不変である.

次に IP に対する抑制効果についてみると, IP 負荷によるHR 増加, dBP 低下，心機能諸指標よ りみたその无進は propranolol により明らかに抑 制されるが, metoprolol, practolol は共に有意な 影響を示さない.IPによる HR 上昇は直接の心機 能促進作用と，末梢血管拡張による洞反射を介す る二次的なものとが推測され゙), metoprolol, practolol の如き心蔵選択性の $\beta$ 遮断剂は propranolol と異なり後者を抑制せず，IP の HR 増
加に対する抑制効果の少ないことはこのような機 序により説明されるかもしれない.しかし metoprolol は practolol 同様に HR のみならず, PEPc, ICP に対する IP 効果も抑制せず，本剂の IP 拮抗性は用量依存的である ${ }^{2)}$ といわれるところ より，本実験で用いた量では， $0.02 \mu \mathrm{g} / \mathrm{kg} / \mathrm{min} の$ IP i. v. に対しては抑制効果を示しえなかったも のと考える方が妥当であろう.

II. 労作性狭心症患者に打ける CA 負荷に対 する metoprolol, practolol の効果

労作性狭心症患者に metoprolol $10 \mathrm{mg}, 40 \mathrm{mg}$, または practolol $100 \mathrm{mg}$ を経口投与してその変 化をみると, 徐脈効果は metoprolol $40 \mathrm{mg}$, practolol $100 \mathrm{mg}$ でいずれも有意であり，前者は 後者より有意に強い. Metoprolol の安静時徐脈作 用は投与量と関係が少ない22ともいわれるが，本 実験で metoprolol $40 \mathrm{mg}$ は $10 \mathrm{mg}$ より強い徐脈 効果を示した。この結果は本症患者に metoprolol を投与した場合，1日量 $20 \mathrm{mg}$ よりも，50 mg で より強い徐脈効果が認められたとする Ekelund らの成績 ${ }^{7}$ と一致する。他方 metoprolol, practolol 共に BP には有意な影響を与えず, CEI, PRI はHR 減少に影響され, metoprolol $40 \mathrm{mg}$ で著し く, practolol では軽度に, metoprolol $10 \mathrm{mg}$ では 後者に近い低下となった。

次にかかる条件下で投与された Ad, NA, IP に よる心仕事量の促進と虚血発症に対する抑制効果 について検討する.

1）Ad 負荷に対する効果：Metoprolol $40 \mathrm{mg}$ 投与により，HR, CEI, PRI は共に有意に低下す る. そして Ad 投与によるこれら諸量の増加は対 照と差をみないが，Ad 負荷後の值はいずれも対 照より低い值を示し，Ad による心電図上の ST 低下は著明に抑制され，狭心痛の出現頻度も明ら かに減少した.一方 practolol $100 \mathrm{mg}$ では HR の みが有意に低下し, CEI, PRI は平均值は低くなる が有意とはいえない.そして Ad 負荷後の HR, CEI, PRI の平均値は対照よりは低いが metoprolol より共に高い値となり, Ad による心電図 ST 低下に対しても，より軽度な抑制効果を示すにと 
どまる。すなわち metoprolol は CEI, PRI より推 測される心仕事量に対し Ad 投与による上昇その ものは抑制しえないが，投与後の值はいずれも対 照より低く，その結果 $\mathrm{Ad}$ 投与による心筋虚血発 症を著明に抑制しえたものと考えられる。そして metoprolol による以上の効果は practolol のそれ に比すれば強い。

2) NA 負荷に対する効果：NA 投与時には, $\mathrm{HR}$ は変化せず, 収縮・拡張期血圧の著しい上昇 とそれに伴う CEI, PRI の上昇がみられる。 これ らの変化に対して metoprolol, practolol は共に 明らかな影響を与えない。しかし metoprolol 投 与後には NA 負荷前後とも CEI, PRI の值は対照 より低く, practolol 投与後は対照と metoprolol の中間の值をとる. そして心電図 ST は NA 投与 により, 5 例中 3 例が $0.5 \mathrm{~mm}$ 以上の低下を生じ, この 3 例の ST の低下はいずれも metoprolol, practolol 前投与により抑制された。つまり NA では主として昇圧に伴ら心仕事量増大がみられる が, metoprolol はHR を低值に保ち, CEI, PRI を 低く抑元, practolol は metoprolol よりやや劣る が同様の効果により共に ST の低下を改善すると 考学られた。

3) IP に対する効果： $\beta$ 遮断剂非投与時には, IP 負荷により HR は著しく増加し, $\mathrm{dBP}$ は低下, CEI, PRI は著明に上昇し, ST は全例 $0.5 \mathrm{~mm}$ 以上 低下する.そして metoprolol はこのような IP に よる HR, CEI, PRI の上昇, ST の低下を抑制乃至 は抑制の傾向を示す.一方 practolol は IP による HR の増加を抑制すると共に, sBP をやや低下せ しめ, CEI, PRI の上昇そのものに対する抑制効果 は metoprolol よりやや著しい.

しかし，先にも述べた如く, CEI 拈よび PRI は metoprolol により IP 投与前値がすでに低值と なって扣り, IP 後の平均値は practolol とほぼ等 しい値となる，そして IP による心電図 ST の低 下に対する抑制効果もほぼ等しい。すなわち $\mathrm{Ad}$, $\mathrm{NA}$ とは異なり，比較的純粋な $\beta$ 受容体刺激剂で ある IP の負荷に対しては, metoprolol $40 \mathrm{mg}$, practolol $100 \mathrm{mg}$ は共に HR の上昇を明らかに
抑光, CEI, PRI の上昇を抑制し, ST 低下を改善 した.これらの効果は $\alpha$ 刺激作用を有する Ad や $\mathrm{NA}$ と異なり, 明瞭な $\beta$ 受容体刺激に対する阻害 作用として理解しうるものであろう。な抗ここで 述べた狭心症患者に対する. IP 拮抗効果は先に述 べた健常人に扣ける i.v. のそれと成績を異にす るが，両者の差異は主として投与法 ${ }^{8)}$ (i. v. と p. o.), 投与量 (metoprolol は $10 \mathrm{mg}$ と $40 \mathrm{mg}^{8}$ ), practolol では $40 \mathrm{mg}$ と $100 \mathrm{mg}$ ) および最大効果 発現までの時間息よりみて投与後の測定時間 (40 $\min$ と $105 \sim 135 \mathrm{~min}$ ) 等の相違に起因しょう。し かしその他に, IP 単独投与による sBP の上昇, $\mathrm{dBP}$ の下降, 殊に後者は健常人群で著しく, 患者 群では極く軽度であった. 従って $\mathrm{HR} \times$ 平均血圧 で表わされるCEIは健常人群では軽度な増加にと どまり,かつ metoprolol $10 \mathrm{mg}$, practolol $40 \mathrm{mg}$ でいずれも HR は抑制されず, dBP 下降がやや軽 度となるためその増加は抑制されない，他方患者 群では CEI の著しい増加が metoprolol $40 \mathrm{mg}$, practolol $100 \mathrm{mg}$ で抑制される違いがみられた. すなわち CEI に対する両群間の効果の差違につ いては, 先に述べた要因に加え, 両群の IP 投与時 の血管反応性の違いも一部関与するといえよう. な抗この違いについては, 若年群と老年群に IP を投与し，若年者で全末梢抵抗の低下が著しかっ たとする桑島ら ${ }^{9}$ の成績と関連して, 両群間では 年齢差（健常人群平均 : 21 歳, 患者群平均 : 57.7 歳）が著しいことも一因であると推察される。と もあれ metoprolol 自体が患者で $\beta$ 遮断効果を持 つことは明確なところであり，また Ad, NA, IP のいずれを問わず CA 投与時の虚血発症を抑制 することは明らかな事実として認められた。

以上 metoprolol は, 殊に $40 \mathrm{mg} \mathrm{p.o.により,}$ 労作性狭心症患者で CA 負荷により発生する心 筋虚血を明らかに抑制し，少なくとも practolol $100 \mathrm{mg}$ と同等かあるいはそれ以上の効果を有す るものと思われた。労作性狭心症はストレスによ り心筋虚血が発症するものであり，その機序には ストレス時の CA 分泌六進が関与することは既 に教室の成績 ${ }^{344)}$ が示すところである.そして 
metoprolol はこの CA による心機能六進の抑制 と, 颃そらくはこれに加えて, propranolol 同様 に，心筋代謝の促進を抑制する゙)ことにより虚血 発症を抑止するものと考えられる。

\section{結 語}

心蔵選択性で，かつ内因性交感神経刺激作用括 よび膜安定作用を持たない $\beta$ 遮断剂である metoprolol の臨床上の作用効果とその特性を検討する ため, 健常成人ならびに労作性狭心症患者に metoprolol を投与し, 本剤の直接効果と, その後 に投与された adreraline (Ad), noradrenaline (NA), isoproterenol (IP) の作用に対する抑制効 果を propranolol, practolol と対比検討し, 以下 の成績を得た。

1) 健常人 (10 例)に拈ける i.v. $20 \mathrm{~min}$ 後の成 績では, metoprolol $10 \mathrm{mg}$ で，心拍数 (HR), 収 縮期血圧 (sBP)，心負担係数 (CEI) はいずれも有 意に低下し，心機図により測定された corrected preejection period $(\mathrm{PEPc})$, isometric contraction period (ICP) は延長し, PEP - ejection time 比 (PEP/ET) は上昇した。他方 propranolol $10 \mathrm{mg}$ では HR は低下し, 拡張期血圧 (dBP) は上昇し, CEI は低下し, PEPc, ICP は延長し, PEP/ET は 上昇した. Metoprolol $10 \mathrm{mg}$ では propranolol 10 mg とほぼ同程度の心拍技よび心機能抑制効果が 認められた。な拉 practolol $40 \mathrm{mg}$ では軽度の $\mathrm{HR}$ 低下傾向以外有意な变化は認められなかっ た.しかし上述量の metoprolol, practolol（健常 人 5 例, i. v. 後 $20 \mathrm{~min}$ ) は IP $0.02 \mu \mathrm{g} / \mathrm{kg} / \mathrm{min}$ に よる HR 増加, $\mathrm{sBP}$ 上昇, $\mathrm{dBP}$ 低下, $\mathrm{PEPc}, \mathrm{ICP}$ 短縮, PEP/ET 低下に著変を示さず, propranolol は sBP を除き抑制した。

2) 労作性狭心症患者 (11 例) への p.o. 投与に より, metoprolol $40 \mathrm{mg}$ は HR, CEI, pressure rate index (PRI) をいずれも有意に低下せしめ る. Practolol $100 \mathrm{mg}$ は HR のみを有意に抑兄, HR, CEI, PRI に対する抑制効果は metoprolol が practolol に比し有意に強い.

3 ) 同じく狭心症患者 ( 9 例) では Ad 投与 $(0.1$ $\mu \mathrm{g} / \mathrm{min}, 15 \mathrm{~min})$ により $\mathrm{HR}, \mathrm{sBP}, \mathrm{CEI}, \mathrm{PRI}$ は上 昇し, 心電図 ST は著明に低下し，9 例中 7 例に 狭心痛が発現した.これに対し, metoprolol $40 \mathrm{mg}$ と practolol $100 \mathrm{mg}$ 投与は共に Ad 投与後の HR, CEI, PRI の值を低く抑え，いずれもAdによ る心電図 ST の低下を抑制, 狭心痛の出現頻度を 減少させた。

次に NA $(0.2 \mu \mathrm{g} / \mathrm{kg} / \mathrm{min})$ 投与（5 例）では著 しい昇仕と CEI, PRI の上昇をみたが，これらに 対しては metoprolol $40 \mathrm{mg}$, practolol $100 \mathrm{mg}$ の p. o. 投与はいずれも有意な影響を及ぼさなかっ た.しかし NA 投与後の HR, CEI, PRI はいずれ も対照より低值になり，5例中 3 例にみられた ST $0.5 \mathrm{~mm}$ 以上の低下は両剂により明らかに抑 制された.

また IP $(0.02 \mu \mathrm{g} / \mathrm{kg} / \mathrm{min})$ 投与（5 例）により HR, CEI, PRI は著明に上昇し, 全例において 0.5 $\mathrm{mm}$ 以上の $\mathrm{ST}$ 低下を示し, 5 例中 3 例に狭心痛 出現をみた. Metoprolol $40 \mathrm{mg}$, practolol $100 \mathrm{mg}$ の前投与は共に IP による HR, CEI, PRI の上昇 に対し抑制ないし抑制する傾向を示し，ST の低 下と狭心痛の出現を全例で抑止した。

\section{謝 辞}

稿を終るにあたり，本研究にご協力下さった飯村 攻助教授および教室員各位に感謝の意を表します。

\section{文 献}

1) Ảblad, B., Carlsson, E. and Ek, L. : Pharmacological studies of two new cardioselective adrenergic beta-receptor antagonists. Life Sci., 12 : 107-119 (1973).

2）藤沢薬品工業 K. K 並びに日本チバガイギ-K. K. 編：CF-15 (Metoprolol) の概要 (基礎編), (1972).

3) Miyahara, M. : A role of sympathoadrenal system in pathogenesis of ischemic heart disease. Acta Cardiol. Suppl., 13: 174-187 (1969).

4) Iimura, O. and Miyahara, M. : Ischemic heart disease and catecholamines. Jap. Circ. J., 35 : 973-978 (1971).

5) Furnival, C. M., Linden, R. J. and Snow, H. M. : Chronotropic and inotropic effects of isoprenaline and 1-noradrenaline in the dog 
heart. J. Physiol., 196 : 109-110 (1968).

6) Johnsson, G., Nyberg, G. and Sölvell, L. : Influence of metoprolol and propranolol on hemodynamic effects induced by physical work and isoprenaline. Acta pharmacol. et toxicol., 36 : Suppl. V : 69-75 (1975).

7) Eklund, L. G., Olsson, A. G., Orö, L. and Rössner, S. : Effects of the cardioselective betaadrenergic receptor blocking agent metoprolol in angina pectoris. Brit. Heart J., 38 : 155-161 (1976).

8) Johnsson, G., Regårdh, C-G., : Combined pharmacokinetic and pharmacodynamic studies in man of the adrenergic $\beta_{1}$-receptor antagonist metoprolol. Acta pharmacol. et toxicol., 36 : Suppl. V, 31-44 (1975).

9) 桑島膂, 蔵本築, 松下哲ほか: 老年者扣よび若 年者に打忛る Noradrenaline, Isoproterenol 反応性の比較. 日老医誌(抄録), $13: 50$ (1976).

10）飯村攻, 浜上裕一ほか: 実験的冠不全犬に関す る研究 (第 5 報) 実験的冠不全犬に打ける adrenaline, noradrenaline 投与に対する交感 神経 $\beta$ 受容体遮断剂 (propranolol) の効果につ いて. 日循誌. (抄録), $38: 125$ (1974). 